\title{
The Influence of Leadership Styles on Organizational Commitment: The Moderating Effect of Emotional Intelligence
}

\author{
Ali Hussein Alkahtani \\ Correspondence: Ali Hussein Alkahtani, King Abdul Aziz University, P.O. Box 80201, Jeddah, 21589 Saudi Arabia
}

Received: September 15, 2015 Accepted: September 28, 2015 Online Published: October 10, 2015

doi:10.11114/bms.v2i1.1091

URL: http://dx.doi.org/10.11114/bms.v2i1.1091

\begin{abstract}
Organizations need employees who are committed in their work so that they can contribute to the survival of the organization in the marketplace competition. Organizational commitment can be divided into three components; normative, affective and continuance commitment. There are various factors that influence employees' commitment. These factors can be categorized into four groups; organizational factors, including leadership, culture, structure and processes; individual factors, including personality traits, emotional quotient, intellectual quotient, and spiritual quotient; job factors, including job characteristics, and remuneration systems; and environment factors, including social relationships and physical environment. This paper is meant to discuss on the influence of the most dominant organizational factor; leadership styles, on employees' organizational commitment by concentrating on the effect of leaders' emotional intelligence. Leadership styles are hypothesized to significantly influence the three types of employees' organizational commitment. Besides, leaders' emotional intelligence is hypothesized to enhance the relationship between leadership styles and employees' organizational commitment. The practical and research implications of the paper are also discussed.
\end{abstract}

Keywords: leadership styles, organizational commitment, emotional intelligence

\section{Introduction}

\subsection{Background of the Study}

Organizational commitment is a common phenomenon which has been extensively addressed by many researchers worldwide due to its importance to the organization (e.g. Angle \& Perry, 1981; Kim, 2001; Lio \& Nyhan, 1994; Lo, Ramayah, \& Min, 2009). Organizational commitment has been linked to the performance of organizational constituents, their loyalty, organizational citizenship behavior, counterproductive behavior, employees' aggression, job satisfaction, and other individual and group constructs. Committed employees are expected to perform at a greater level than their uncommitted counterparts (Meyer, Paunonen, Gellatly, Goffin, \& Jackson, 1989). They are willing to work extra hours when the job requires them to do so. They are also willing to promote the organization as a favorable place to work at. Due to its diverse accrued benefits to the organization, some researchers have devoted their effort to investigate the antecedents of organizational commitment (e.g. Bateman \& Strasser, 1984; Lok \& Crawford, 2004; Meyer, Allen, \& Smith, 1993). These factors can be categorized into four groups; organizational factors, including leadership, culture, structure and processes; individual factors, including personality traits, emotional quotient, intellectual quotient, and spiritual quotient; job factors, including job characteristics, and remuneration systems; and environment factors, including social relationships and physical environment. The focus of this paper is on the influence of leadership styles on employees' organizational commitment.

Leadership style is the most prevalent factors that influence employees' attitudes and behaviors including organizational commitment. Leaders have adopted various styles when they lead others in the organization (Brown, 2003; Cheong, 2008; Chiang \& Wang, 2012; Clark, Hartline, \& Jones, 2009; Cox, 2001). Some are using democratic, people or relationship centered approach and others prefer autocratic, production centered method in order to achieve a similar goal, which is organizational effectiveness. The choice of a style is contingent on diverse factors such as personality traits of leaders, followers' acceptance of the leaders, their readiness, task complexity and the norms and values embraced by the organizational members. Therefore, leaders must possess special ability to diagnose the organizational environment, accurately identify the contingent factors and subsequently make a sound decision in leading the organization towards success. Here, emotional intelligence ability offers great help to guide a leader in choosing the 
right leadership styles.

Emotional intelligence is a set of abilities to accurately assess the emotions of self and others, regulate the emotions to achieve the desired state and use the emotions towards achieving the expected performance (Mayer \& Salovey, 1997). Emotional intelligence has been defined differently by different authors but the objective of having this intelligence is similar; to achieve the desired emotional state so that the employees are able to attain their expected performance. Leaders with high emotional intelligence are able to correctly scan the organizational environment, weigh the possible consequences of their actions and select the most appropriate leadership styles acceptable by the followers. This paper is meant to highlight the critical role of emotional intelligence in influencing leaders' choice of styles and its relationship with employees' organizational commitment, which comprises normative, affective and continuance commitment. Existing work in this area is discussed and relevant propositions are formulated to facilitate the future effort towards the enrichment of the related knowledge.

\subsection{Organizational Commitment}

The common definition of commitment does not really exist (Morris \& Steers, 1993) because different authors provide different definitions for the construct. Mowday, Porter and Steers (1982) defined commitment as the relative strength of an individual's identification with an organization and involvement in the organization. In some cases a distinction is made between organizational commitment and task commitment (Peeters \& Meijer, 1995). Gallie and White (1993) asserted that the term "organizational commitment" refers to the acceptance of organizational values and the willingness to stay. Task commitment, on the other hand, reflects the effort one puts into his or her work. Porter, Steers, Mowday, \& Boulian (1974) and Mowday, Steers and Porter (1979) defined organizational commitment as a strong belief in the organization and willingness to exert significant effort towards the organization. Commitment to organization is linked to very important work-related factors such as employee absenteeism, employee turnover and employee job performance (Mowday, Porter, \& Dubin, 1974; Mowday, Steers \& Porter, 1979; Romzek, 1990; Ward \& Davis, 1995).

Organizational commitment is categorized into three components; affective, continuance and normative commitments (Allen \& Meyer, 1990; 1996). Affective commitment concerns the employee's emotional attachment to, identification with and involvement in the organization. Affective commitment involves three aspects: (1) the formation of an emotional connection to an organization, (2) identification with an organization (3) and the desire to maintain and become loyal with organizational membership. Affective commitment exists when an employee identifies with an organization and its goals (Mowday, et al., 1979). Allen and Meyer (1997) said that employees retain to be members of the organization and try to increase their productivity.

Continuance commitment, on the other hand, refers to employees' assessment of whether the costs of leaving the organization are greater than the costs of staying. Employees who perceive that the costs of leaving the organization are greater than the costs of staying will remain with the organization. In contrast to the other two components of organizational commitment, continuance commitment does not relate to emotion. It mostly relates to the investments the employees make in an organization such as job effort, time and development with work friendships, skills and political deals (Jaros, Jermier, Koehler, \& Sincich, 1993). Allen and Meyer (1990) enumerated the concept of continuance commitment as a form of psychological attachment to an employing organization that reflects the degree to which an individual experiences a sense of being locked in place because of high cost of leaving.

Normative commitment refers to employees' feelings of responsibility to the organization. Employees with high levels of normative commitment stay with the organization because they feel that they have to. In arguing for their framework, Meyer and Allen (1991) contended that affective, continuance, and normative commitment were components rather than types because employees could have varying degrees of all three. They exemplified the three types of commitment by saying that one employee might feel both a strong attachment to an organization and a sense of responsibility to remain. A second employee might enjoy working for the organization but also recognize that leaving would be very difficult from an economic perspective. Finally, a third employee might experience a considerable degree of desire, need, and responsibility to remain with the current employer (Allen \& Meyer, 1997). According to Randall and O'driscoll (1997), normative commitment is an employees' moral commitment that is present when an organization provides moral value and financial support for its employees' development and requirement.

\subsection{Leadership Styles}

Leadership style is the approach of providing direction, implementing plans, and motivating people (Northouse, 2015). Leaders should identify the best leadership style to manage their employees in the organization. Harry S. Truman, $33^{\text {rd }}$ President of the United States once said, "A leader is a man who can persuade people to do what they do not want to do, or do what they are too lazy to do". Leadership is a process, involves influence, occurs within a group contact, and involves goal attainment. Using this claim, leadership is defined as a process where an individual influences a group of other individuals to achieve a common goal. In other words, the leader is the inspiration and director of the action. He 
or she is the person in the group that possesses the combination of personality and skills that make others want to follow his or her direction. In business, leadership is strongly linked to performance. Effective leaders are those who are able to increase their company's bottom lines.

Leadership is very important in order to manage and control employees and organizations. The suitability of leadership styles to be used in an organization is based on the sector of business in which they are operating. An effective leader is someone who knows how to inspire and relate to subordinates, knows how to increase the employees' motivation and make employees loyal to the organization. The most universal leadership styles concerns transactional, transformational and laissez-faire. These three styles are commonly applied in various organizations nowadays. Transactional leadership is about power to perform certain tasks and reward or punish according to employees' performance. If employees perform well, the leader will reward them, but if their performance is not as expected, they will be punished. In transformational leadership, leaders show the value of workers concentrating on what benefits their work team can achieve rather than on individual interests, they know how to motivate employees, know how to read them and know how to handle them. In laissez-faire leadership style, leaders have minimum involvement in decision making. They allow employees to make their own decisions but they are still responsible for the outcome. Laissez-faire works best when people are capable and motivated in making their own decision and opinion. The employees are confident and there is no requirement for central coordination.

\subsubsection{Transformational versus Transactional Leadership Styles}

Previous studies have established that transformational leadership is the most preferred by employees in organizations. According to Burns (1978), transformational leadership links the power of a position to respond to the needs of the followers. In this style, the vision of the leader must be conveyed to the follower. This vision sometimes requires change in the organization. This style is becoming increasingly important because of the demand for the organization to change in today's world of globalization. It is important for transformational leaders to motivate the followers regarding their vision.

Transformational leaders motivate followers to be better in many ways (Avolio \& Bass, 1988; Burns, 1978). The leaders concentrate on teamwork rather than individual interests. Transformational leadership clearly defines the roles of the leader and followers but also includes the followers in the leadership process. Effective leadership requires leading others to think innovatively and promoting the continual discovery of new solutions to the problems that they are facing. To get people to work toward a common goal is not easy. Research suggests that leaders need to have qualities that facilitate followers to transform from one situation to another and they are transformational (Shamir, House, \& Arthur, 1993; Yukl, 1999). Transformational leadership can motivate employees to go beyond their own self-interest and pursue goals and encourage employees to become more productive. Transformational leadership encourages followers to accomplish more than what would normally be expected of them and they are motivated to relinquish their own interest for the good of employees or organization (Barnett, McCormick, \& Conners, 2001; Bass \& Avolio, 1997; Northhouse, 2015).

Transformational leadership is also defined in terms of how the leader affects followers, who are intended to trust, admire and respect the leader (Bass \& Steidlmeier, 1998). But for laissez-faire style, the involvement of leaders in decision-making is minimal and hence allows people to make their own decisions, although the leaders are still responsible for the outcome. The transactional leadership style was first described by Max Weber in 1947, and again by Bernard M. Bass in 1985. Transformational leadership is the one end of leadership spectrum and transactional leadership is its opposite end. There is no single method which has been found to be successful in all situations (Bass, $1985 ; 1997 ; 1998)$. However, the focus of leadership has shifted from transactional models of leadership to new genre of leadership theories by highlighting on transformational leadership (Bass, 1985). Transformational leadership can be divided into four factors;

\section{1) Idealized Influence}

Idealized influence is the behavior that encourages the followers to use their leaders as role models. Idealized influence leaders have high moral and ethical values and are able to provide their followers with a sense of vision and mission. In most situations, followers greatly respect the idealized influence leader (Northouse, 2001).

\section{2) Individualized Consideration}

Individualized consideration is shown by the transformational leader by creating a supportive climate, listening to their employees, and acts as a coach and mentor which the leaders show consideration for their employees' needs. Leaders pay close attention to individual differences and treat their employees in the most caring way. Leaders also help individuals to achieve goals and personal development. This type of leaders also uses delegation to get their employee to grow through personal challenges (Northouse, 2015). 


\section{3) Inspirational Motivation}

Inspirational motivation is about raising the consciousness of the employees by motivating and inspiring them to demonstrate commitment to the vision and mission of the group in the organization. The inspirational motivational leaders engage in clearly communicating high expectations to followers and increase team spirit and enthusiasm (Northouse, 2015).

\section{4) Intellectual Stimulation}

Intellectual stimulation is demonstrated by the leaders when they support their employees to be creative and innovative and to try new approaches and challenge their own beliefs and values. This type of leaders promotes problem solving to find creative solutions (Northouse, 2015).

Transactional leadership concerns the power to perform certain tasks and reward or punish for employees' performance (Burns, 1978). It gives the opportunity to leaders to lead the employees and they agree to follow their leaders to accomplish the goals. Power is given to the leaders to evaluate, train and correct and handle the employees when productivity is below the expectation level and reward appropriately when the expected outcome is reached. However, findings of the previous studies on transactional leadership show mixed results. Reward leadership has been found in many cases to be highly correlated to transformational leadership (Avolio, Bass, \& Jung, 1999). In general, active leadership is found to be more effective than passive leadership. However, Howell and Avolio (1993) argued that if the predominant style of the leader is to take corrective action, such behavior is expected to have a negative impact on followers' performance. There are three factors in transactional leadership style which are;

\section{1) Contingent Reward}

Managers who use the contingent reward leadership show the standards, and encourage their employees to perform well because the leaders will let their employees know the rewards they will receive if their performance level is high. Subordinates are promised rewards for good performance but if the performance is bad they will receive the punishment (Bass, 1985; Avolio, et al., 1999).

\section{2) Management by Exception (Active)}

Management-by-Exception (active) occurs when leaders make corrective criticisms or use negative reinforcement. This leadership behavior monitors employees closely in order to identify mistakes and errors. Leaders with Management-byException with "active" behaviors are characterized as monitoring followers' performances and taking corrective action if deviations from the set standards occur. These leaders enforce rules to avoid mistakes.

3) Management by Exception (passive)

In this leadership style, leaders use Management-by-Exception (passive), only intervene when goals have not been met or a problem arises. The Management-by-Exception leader with a "passive" behavior would not get involved until problems become serious. The Management-by-Exception (passive) leaders wait to take action until mistakes are brought to their attention. Laissez-faire behaviors normally involve the postponement of decisions and capitulation of responsibility. Laissez-faire leaders offer no feedback or support to the follower. Laissez-faire leadership is a "hands-off" approach to leadership (Northouse, 2015).

\subsection{The Relationship between Transformational Leadership Styles and Organizational Commitment}

Previous research has devoted a great deal of attention to the relationship between leadership behavior and employees' commitment. Several studies found a positive relationship between the two variables (Kent \& Chelladurai, 2001; Leach, 2005; Pearce \& Herbik, 2004). According to Stum (1999), employees' commitment reflects the quality of the leaderships styles used in the organization. Thus, it is logical to think that leadership behavior would have a significant correlation or relationship with employees' commitment. Previous research suggests a positive direct relationship between leadership behaviors and employees' commitment.

Morris and Steers (1993) Ananthi and Subramaniam (2011) have established the link between leadership behavior and employees' commitment. Brief, Aldag and Wallden, (1976), investigated police officers' commitment and found high positive relationship between respect for their supervisors and organizational structuring level. Den Hartog and Belschak (2012), Hill, Seo, Kang, and Taylor (2012) and Mowday, et al. (1982) also found that there was a positive relationship between leader's behavior and employees' commitment. Lee (2008) found out that transformational leadership significantly correlates with employees' commitment with the sample of professionals in Singapore. On the other hand, Hayward, Goss and Tolmay (2004) noted that transformational leadership has moderate positive correlation with affective commitment. Besides, the researcher also found that there is a lower correlation between transformational leadership, normative and continuance commitment.

Billingsley and Cross (1992) reported a positive relationship between leader support and commitment. In three separate 
studies, Popper, Mayseless and Castelnovo (2000) found evidence supporting a positive correlation between transformational leadership and attachment. Podsakoff, MacKenzie and Bommer (1996) found that leadership behaviors explained $48 \%$ of the variance in organizational commitment. Kent and Chelladurai (2001) found that individualized consideration has positive correlation with both affective commitment and normative commitment. Besides, the researchers also found positive correlations between intellectual stimulation and both affective commitment and normative commitment.

Shamir, House and Arthur (1993) and Shamir, Zakay, Breinin and Popper (1998) suggest that transformational leaders are able to influence followers' organizational commitment by promoting higher levels of intrinsic value associated with goal accomplishment, emphasizing the linkages between followers' effort and goal achievement, and by creating a higher level of personal commitment on the part of the leader and followers to a common vision, mission and organizational goals. Transformational leaders influence followers' organizational commitment by encouraging them to think critically by using novel approaches, involving followers in decision-making processes and inspiring loyalty while recognizing and appreciating the different needs of each follower to develop his or her personal potential (Bass \& Avolio, 1994; 1997; Yammarino, Spangler \& Bass, 1993). By encouraging followers to seek new ways to approach problems and challenges and identifying with followers' needs, transformational leaders are able to motivate their followers to get more involved in their work, resulting in higher levels of organizational commitment (Walumbwa \& Lawler, 2003). This view was supported by prior research showing that organizational commitment was higher for employees whose leaders encouraged participation in decision-making (Jones \& Rudd, 2008; Scott-Ladd, Travaglione, \& Marshall, 2006), emphasized on consideration (Bycio, Hackett \& Allen, 1995) and were supportive and concerned for their followers' development (Allen \& Meyer, 1990; 1996; 1997)

Other researchers, Kent and Chelladurai (2001) stated that individualized consideration has positive relationship with both affective commitment and normative commitment. Other than that, the researcher also found that there is positive correlation between intellectual stimulation and both affective commitment and normative commitment. Bass and Avolio (1994) discovered that transformational leaders who encourage their followers to think critically and creatively have an influence on their followers' commitment. This is further supported by Walumbwa and Lawler (2003) that transformational leaders can motivate and increase followers' motivation and organizational commitment by getting them to solve problems creatively and also understanding their needs. Ko, Price and Mueller (1997) further suggested that employees are far more likely to be committed to the organization if they have confidence in their leaders. Hence, the appropriate propositions are formulated as follow:

P1 Idealized influence leaders have positive influence on employees' affective commitment

P2 Individualized consideration leaders have positive influence on employees' affective commitment

P3 Inspirational motivational leaders have positive influence on employees' affective commitment

P4 Intellectual stimulation leaders have positive influence on employees' affective commitment

P5 Idealized influence leaders have positive influence on employees' continuance commitment

P6 Individual consideration leaders have positive influence on employees' continuance commitment

P7 Intellectual stimulation leaders have positive influence on employees' continuance commitment

P8 Inspirational motivational leaders have positive influence on employees' continuance commitment

P9 Idealized influence leaders have positive influence on employees' normative commitment

P10 Individual consideration leaders have positive influence on employees' normative commitment

P11 Intellectual stimulation leaders have positive influence on employees' normative commitment

P12 Inspirational motivational leaders have positive influence on employees' normative commitment

\subsection{The Relationship between Transactional Leadership Style and Organizational Commitment}

Transactional leadership has been found to have significant relationship with organizational commitment but it is a weak relationship (Alqudah, 2011). Brown and Dodd (1999) earlier claimed that transactional leadership has a negative association with affective, normative and continuance commitment. Based on this premise, the following propositions are constructed:

P13 Contingent reward leaders have negative influence on employees' affective commitment

P14 Management-by-Exception leaders have negative influence on employees' affective commitment

P15 Contingent reward leaders have negative influence on employees' continuance commitment

P16 Management-by-Exception leaders have negative influence on employees' continuance commitment 
P17 Contingent reward leaders have negative influence on employees' normative commitment

P18 Management-by-Exception leaders have negative influence on employees' normative commitment

\subsection{Definitions of Emotional Intelligence}

An early definition of Emotional Intelligence (EI) by Salovey and Mayer (1990, p. 189) describes it as the subset of social intelligence that involves the ability to monitor one's own and others' feelings and emotions to discriminate among them and to use this information to guide one's thinking and actions. Building on Salovey and Mayer's work, Goleman (2000) identified the abilities that EI involves and categorized these EI competencies into five areas; self-awareness, self-regulation, self-motivation, empathy and social competencies. EI is demonstrated when a person uses competencies that constitute self-awareness, self-management, social-awareness, and social skills at the right times, in the correct ways and in sufficient frequency to be effective in the situation (Boyatzis, Goleman, \& Rhee, 2000). The emotional competence inventory (ECI), developed by Boyatzis, Goleman and others, uses four clusters; self-awareness, social awareness, self-management and social skills.

Emotional Intelligence reflects people's or leaders' ability to do their jobs well, the degree of employees' flexibility in doing their jobs, ability to innovate and ownership of and responsibility for their work and the level of the performance standards. Emotionally intelligent leaders have been found to contribute to increased individual and organizational performance (Carmeli, 2003; Nikolaou \& Tsaousis, 2002; Parasuraman \& Nachman, 1987; Weinberger, 2003; Wong \& Law, 2002). It also has been linked with increased organizational effectiveness performance (Cherniss \& Goleman, 2001). Prati, Douglas, Ferris, Ammeter and Buckley (2003) developed a model connecting emotional intelligence with leadership, team process and outcomes. The model highlights emotional intelligence abilities as the key for effective team leadership and successful team outcomes. The relationship between leadership styles used by leaders and employees' organizational commitment can be moderated by the extent of emotional intelligence the leaders have. According to Mohamadkhani and Nasiri Lalardi (2012), there is a highly significant relationship between emotional intelligence and organizational commitment where emotional intelligence of leaders increases employees' organizational commitment.

\subsection{Emotional Intelligence (EI) and Leadership Styles}

A significant relationship between emotional intelligence competencies and individual performance has been established for some time (Boyatzis, 1982). Emotionally intelligent managers or leaders have been found to contribute to increased individual and organizational performance (Carmeli, 2003; Nikolaou \& Tsaousis, 2002; Parasuraman \& Nachman, 1987; Weinberger, 2003; Wong \& Law, 2002). Emotional intelligence has been linked to increased organizational effectiveness across a broad range of areas (Cherniss \& Goleman, 2001). Those with high emotional intelligence are more likely to be able to become effective leaders (Goleman, 2000). Goleman, Boyatzis and McKee (2002) have demonstrated a clear link between emotional intelligence, leadership style and organizational performance. The importance of the leadership style has been researched and discussed widely, including the link between leadership style and emotional intelligence (Mandell \& Pherwani, 2003; Turner \& Müller, 2005; Turner \& Lloyd-Walker, 2008). Mandell and Pherwani (2003) found a significant relationship between transformational leadership style and emotional intelligence of leaders. Prati, et al. (2003) developed a model linking emotional intelligence, leadership, team processes and outcomes. Prati, et al. (2003) claimed that emotional intelligence abilities are critical for effective team leadership and successful team outcomes.

\subsubsection{Emotional Intelligence and Transformational Leadership}

Emotional Intelligence supports the improvement of a transformational leadership style, and the combination of transformational leadership style and emotional intelligence abilities have the potential to improve project outcome (Leban \& Zulauf, 2004). Butler and Chinowsky (2006) studied the relationship between emotional intelligence and transformational leadership styles of project managers in the construction industry. They found that interpersonal skills and empathy are key emotional intelligence behaviors required by construction industry executives if the industry is to achieve more successful project outcomes in the future. The positive relationship between emotional intelligence and transformational leadership has also been established by other researchers (Barbuto \& Burbach, 2006).

Goleman, et al. (2002) introduced the concept that emotional intelligence is not only a power enhancer, but it is also an essential component of successful leadership. Goleman, et al.'s (2002) model of emotional intelligence identifies four critical domains, which are broken down into 18 competencies. The model demonstrates that the leadership skills which contribute to leader success require the inclusion of emotional intelligence abilities. Leader attributes include a range of interpersonal skills are closely linked to emotional intelligence abilities; listening, empathy and awareness (Greenleaf, 2003); influencing skills, developing, coaching and nurturing (Maccoby, 2000) developing plans, setting goals and demonstrating strong emotional self-management (Humphrey, 2002) and self-control (Goleman, et al., 2002). 
To sum up the discussion, the following propositions are emphasized:

P19 Emotional Intelligence enhances the influence of idealized influence leaders on employees' affective commitment

P20 Emotional Intelligence enhances the influence of inspirational motivational leaders on employees' affective commitment

P21 Emotional Intelligence enhances the influence of intellectual stimulation leaders on employees' affective commitment

P22 Emotional Intelligence enhances the influence of individualized consideration leaders on employees' affective commitment

P23 Emotional Intelligence enhances the influence of idealized influence leaders on employees' continuance commitment

P24 Emotional Intelligence enhances the influence of inspirational motivational leaders on employees' continuance commitment

P25 Emotional Intelligence enhances the influence of intellectual stimulation leaders on employees' continuance commitment

P26 Emotional Intelligence enhances the influence of individualized consideration leaders on employees' continuance commitment

P27 Emotional Intelligence enhances the influence of idealized influence leaders on employees' normative commitment

P28 Emotional Intelligence enhances the influence of inspirational motivational leaders on employees' normative commitment

P29 Emotional Intelligence enhances the influence of intellectual stimulation leaders on employees' normative commitment

P30 Emotional Intelligence enhances the influence of individualized consideration leaders on employees' normative commitment

\subsubsection{Emotional Intelligence and Transactional Leadership}

Emotional Intelligence supports certain transactional leadership when the leaders use the contingent reward characteristic in order to inspire and motivate employees to perform well. According to Bass (1985) and Bass and Avolio (1997), transactional leadership can be described in terms of two characteristics: the use of contingent rewards and management by exception. They described contingent reward as the reward that the leader will present to the employees once the latter have achieved goals that were agreed upon. Contingent reward is therefore the exchange of rewards for meeting agreed-upon objectives. By combining the transactional leadership and emotional intelligence, the employees will be more committed to their job and increase their job performance. With emotional intelligence abilities, transactional leaders are more able to make and fulfill promises by rewarding employees appropriately and relate the reward given to the employees' performance.

Bass (1985) argues that by providing the contingent rewards, a transactional leader might inspire a reasonable degree of involvement, loyalty, commitment and performance from subordinates. Transactional leaders may also rely on active management by exception which occurs when the leader monitors followers to ensure mistakes are not made, but otherwise, allows the status quo to exist without being addressed (Bass \& Avolio, 1995). In passive management by exception, the leader intervenes only when things go wrong. Coupled with emotional intelligence abilities, transactional leaders are able to make better decisions as to when and how to intervene, to what extent and with whom the intervention should be exercised. It is because the leaders become more sensible to the situations and the needs and readiness of the employees.

Based on the above discussion, the following propositions are highlighted:

P31 Emotional intelligence enhances the positive influence of contingent reward leaders on employees' affective commitment

P32 Emotional intelligence enhances the positive influence of management by exception leaders on employees' affective commitment

P34 Emotional intelligence enhances the positive influence of contingent reward leaders on employees' continuance commitment

P35 Emotional intelligence enhances the positive influence of management by exception leaders on employees' 
continuance commitment

P36 Emotional intelligence enhances the positive influence of contingent reward leaders on employees' normative commitment

P38 Emotional intelligence enhances the positive influence of management by exception leaders on employees' normative commitment

\section{Conclusion}

The review of the existing studies on leadership found that all dimensions of transformational leadership styles; idealized influence, inspirational motivation, intellectual stimulation and individualized consideration, are significantly related to employees' organizational commitment dimensions; continuance, affective and normative. Transactional leadership styles that consist of contingent reward, management by exception (passive) and management by exception (active) are weakly related to the three dimensions of organizational commitment. However, leaders with high emotional intelligence abilities are hypothesized to enhance the relationship between transformational leadership styles and organizational commitment and change the direction of the relationship between transactional leadership styles and organizational commitment of employees in the organization.

\subsection{Managerial Implications}

Leaders in today's globalized business environment characterized by rapid change should be equipped with emotional intelligence abilities so that they are able to effectively exercise their leadership roles. Leadership styles are very much contingent on the organizational environment, thus, rendering none of the leadership style as superior than the other. The emotional intelligent ability of the leaders is crucial to ensure that the leadership styles chosen by the leaders can be executed effectively to enhance the employees' organizational commitment. Emotional intelligence of leaders can be gradually developed through individual reflective exercises where the leaders assess their emotional states as a result of various emotional stimulating events. It can also be developed through frequent observation and assessment of others' emotional states. Besides, it can also be nurtured by continuously applying appropriate strategies to deal with negative as well as positive emotions. These strategies can range from suppressing to amplifying the desired emotions so that the energy emerged from these emotions can be manipulated to stimulate leaders to engage in productive activities. To sum up, emotional intelligence is crucial for leaders to effectively lead others in the organization to achieve the organizational objectives.

\subsection{Suggestions for Future Research}

This paper attempts to integrate the concept of emotional intelligence into the relationship between leadership styles and employees' organizational commitment. The suggested conceptual framework is worthless without the effort to confirm the highlighted propositions using empirical evidence. Thus, future research in this area is highly warranted using the most reliable and valid research instruments and utilizing rigorous methodology and data analysis. It is worth noted that there are abundant of available research instruments relating to the discussed constructs, thus, researchers' discretion is highly required in the selection of the correct ones considering the costs and benefits accrued from using each of them. With correct methodology and data analysis the findings can be generalized across different settings and the existing model can be further enhanced.

\section{References}

Allen, N. J., \& Meyer, J. P. (1990). The measurement and antecedents of affective, continuance and normative commitment to the organization. Journal of Occupational Psychology, 63(1), 1-18. http://dx.doi.org/10.1111/j.2044-8325.1990.tb00506.x

Allen, N. J., \& Meyer, J. P. (1996). Affective, continuance, and normative commitment to the organization: An examination of construct validity. Journal of Vocational Behavior, 49(3), 252-276. http://dx.doi.org/10.1006/jvbe.1996.0043

Allen, N. J., \& Meyer, J. P. (1997). Commitment in the workplace: Theory, research and application. Thousand Oaks, CA: Sage Publications.

Alqudah, T. G. (2011). Leadership styles and organizational commitment. (Master of Business Administration Dissertation, Open University Malaysia).

Ananthi, P., \& Subramaniam, B. (2011). The influence of leadership styles on organizational commitment. (Master Thesis, University Utara Malaysia).

Angle, H. L., \& Perry, J. L. (1981). An empirical assessment of organizational commitment and organizational effectiveness. Administrative Science Quarterly, 26(1), 1-14. http://dx.doi.org/10.2307/2392596 
Avolio, B. J., \& Bass, B. M. (1988). Transformational leadership, charisma, and beyond. In Gerald, H. J., Rajaram, B. B., Peter, D. H., \& Chester A. S. (Eds.). Emerging leadership vistas. International leadership symposia series, (pp. 29-49). Lexington, MA, England: Lexington Books.

Avolio, B. J., Bass, B. M., \& Jung, D. I. (1999). Re-examining the components of transformational and transactional leadership using the Multifactor Leadership. Journal of Occupational and Organizational Psychology, 72(4), 441-462. http://dx.doi.org/10.1348/096317999166789

Barbuto, J. E., \& Burbach, M. E. (2006). The emotional intelligence of transformational leaders: A field study of elected officials. The Journal of Social Psychology, 146(1), 51-64. http://dx.doi.org/10.3200/SOCP.146.1.51-64

Barnett, K., McCormick, J., \& Conners, R. (2001). Transformational leadership in schools-panacea, placebo or problem?. Journal of Educational Administration, 39(1), 24-46. http://dx.doi.org/10.1108/09578230110366892

Bass, B. M. (1985). Leadership and performance beyond expectations. New York, NY: Free Press.

Bass, B. M. (1997). Does the transactional-transformational leadership paradigm transcend organizational and national boundaries?. American Psychologist, 52(2), 130-139. http://dx.doi.org/10.1037/0003-066X.52.2.130

Bass, B. M. (1998). Transformational leadership: Industry, military, and educational impact. Mahwah, NJ: Erlbaum Associates.

Bass, B. M., \& Avolio, B. J. (1994). Transformational leadership and organizational culture. The International Journal of Public Administration, 17(3-4), 541-554.

Bass, B. M., \& Avolio, B. J. (1995). MLQ multifactor leadership questionnaire. Redwood City. CA: Mind Garden.

Bass, B. M., \& Avolio, B. J. (1997). Full range leadership development: Manual for the Multifactor Leadership Questionnaire (pp. 43-44). Palo Alto, CA: Mind Garden.

Bass, B. M., \& Steidlmeier, P. (1999). Ethics, character, and authentic transformational leadership behavior. The Leadership Quarterly, 10(2), 181-217. http://dx.doi.org/10.1016/S1048-9843(99)00016-8

Bateman, T. S., \& Strasser, S. (1984). A longitudinal analysis of the antecedents of organizational commitment. Academy of Management Journal, 27(1), 95-112. http://dx.doi.org/10.2307/255959

Billingsley, B. S., \& Cross, L. H. (1992). Predictors of commitment, job satisfaction, and intent to stay in teaching: A comparison of general and special educators. The Journal of Special Education, 25(4), 453-471. http://dx.doi.org/10.1177/002246699202500404

Boyatzis, R. E. (1982). The competent manager: A model for effective performance. England: John Wiley \& Sons.

Boyatzis, R. E., Goleman, D., \& Rhee, K. (2000). Clustering competence in emotional intelligence: Insights from the Emotional Competence Inventory (ECI). Handbook of Emotional Intelligence, 343-362.

Brief, A. P., Aldag, R. J., \& Wallden, R. A. (1976). Correlates of supervisory style among policemen. Criminal Justice and Behavior, 3(3), 263-271. http://dx.doi.org/10.1177/009385487600300304

Brown, B. B. (2003). Employees' organizational commitment and their perception of supervisors' relations-oriented and task-oriented leadership behaviors (Doctoral dissertation, Virginia Polytechnic Institute and State University).

Brown, F. W., \& Dodd, N. G. (1999). Rally the troops or make the trains run on time: The relative importance and interaction of contingent reward and transformational leadership. Leadership \& Organization Development Journal, 20(6), 291-299. http://dx.doi.org/10.1108/01437739910292607

Burns, J. M. (1978). Leadership. New York, NY: The Free Press.

Butler, C. J., \& Chinowsky, P. S. (2006). Emotional intelligence and leadership behavior in construction executives. $\begin{array}{llll}\text { Journal of } & \text { Management }\end{array}$ http://dx.doi.org/10.1061/(ASCE)0742-597X(2006)22:3(119)

Bycio, P., Hackett, R. D., \& Allen, J. S. (1995). Further assessments of Bass's (1985) conceptualization of transactional and transformational leadership. Journal of Applied Psychology, 80(4), 468-478. http://dx.doi.org/10.1037/0021-9010.80.4.468

Carmeli, A. (2003). The relationship between emotional intelligence and work attitudes, behavior and outcomes: An examination among senior managers. Journal of Managerial Psychology, 18(8), 788-813. http://dx.doi.org/10.1108/02683940310511881

Cheong, L. H. (2008). Investigating the impact of managerial coaching on employees' organizational commitment and turnover intention in Malaysia. (Master Dissertation, University of Malaya, Malaysia). 
Cherniss, C., \& Goleman, D. (2001). Training for emotional intelligence: A model. The emotionally intelligent workplace (209-233). San Francisco, CA: Jossey-Bass.

Chiang, C. F., \& Wang, Y. Y. (2012). The effects of transactional leadership and transformational leadership on organizational commitment in Hotels: The mediating effect of trust. Journal of Hotel and Business Management, $1(1)$.

Clark, R. A., Hartline, M. D., \& Jones, K. C. (2009). The effects of leadership style on hotel employees' commitment to service quality. Cornell Hospitality Quarterly, 50(2), 209-231. http://dx.doi.org/10.1177/1938965508315371

Cox, P. L. (2001). Transformational leadership: A success story at Cornell University. In Proceedings of the ATEM/aappa 2001 conference. Retrieved March (Vol. 17, p. 2004).

Den Hartog, D. N., \& Belschak, F. D. (2012). When does transformational leadership enhance employee proactive behavior? The role of autonomy and role breadth self-efficacy. Journal of Applied Psychology, 97(1), 194-202. http://dx.doi.org/10.1037/a0024903

Gallie, D., \& White, M. (1993). Employee commitment and the skills revolution: First findings from the Employment in Britain Survey. London: Policy Studies Institute.

Goleman, D. (2000). An EI-based theory of performance. In D. Goleman, \& C. Cherniss (Eds).The emotionally intelligent workplace: How to select for, measure, and improve emotional intelligence in individuals, groups, and organizations. San Francisco, CA: Jossey-Bass.

Goleman, D., Boyatzis, R. E., \& McKee, A. (2002). The new leaders: Transforming the art of leadership into the science of results. London: Little, Brown.

Greenleaf, R. K. (2003). Motion and emotion. Principal Leadership, 3(9), 14-19.

Hayward, Q., Goss, M., \& Tolmay, R. (2004). The relationship between transformational and transactional leadership and employee commitment. Grahamstown, Rhodes University: Business Report.

Hill, N. S., Seo, M. G., Kang, J. H., \& Taylor, M. S. (2012). Building employee commitment to change across organizational levels: The influence of hierarchical distance and direct managers' transformational leadership. Organization Science, 23(3), 758-777. http://dx.doi.org/10.1287/orsc.1110.0662

Howell, J. M., \& Avolio, B. J. (1993). Transformational leadership, transactional leadership, locus of control, and support for innovation: Key predictors of consolidated-business-unit performance. Journal of Applied Psychology, 78(6), 891-902.

Humphrey, R. H. (2002). The many faces of emotional leadership. The Leadership Quarterly, 13(5), 493-504. http://dx.doi.org/10.1016/S1048-9843(02)00140-6

Jaros, S. J., Jermier, J. M., Koehler, J. W., \& Sincich, T. (1993). Effects of continuance, affective, and moral commitment on the withdrawal process: An evaluation of eight structural equation models. Academy of Management Journal, 36(5), 951-995. http://dx.doi.org/10.2307/256642

Jones, D., \& Rudd, R. (2008). Transactional, Transformational, or Laissez-Faire Leadership: An Assessment of College of Agriculture Academic Program Leaders'(Deans) Leadership Styles. Journal of Agricultural Education, 49(2), 88-97.

Kent, A., \& Chelladurai, P. (2001). Perceived transformational leadership, organizational commitment, and citizenship behavior: A case study in intercollegiate athletics. Journal of Sport Management, 15(2), 135-159.

Kim, B. S. (2001). Commitment of Malaysian workers in Korean multinational enterprises. Malaysian Management Review, 36(1), 63-75.

Ko, J. W., Price, J. L., \& Mueller, C. W. (1997). Assessment of Meyer and Allen's three-component model of organizational commitment in South Korea. Journal of Applied Psychology, 82(6), 961-973. http://dx.doi.org/10.1037/0021-9010.82.6.961

Leach, L. S. (2005). Nurse executive transformational leadership and organizational commitment. Journal of Nursing Administration, 35(5), 228-237.

Leban, W., \& Zulauf, C. (2004). Linking emotional intelligence abilities and transformational leadership styles. Leadership \& Organization Development Journal, 25(7), 554-564. http://dx.doi.org/10.1108/01437730410561440

Lee, J. (2008). Effects of leadership and leader-member exchange on innovativeness. Journal of Managerial Psychology, 23(6), 670-687. http://dx.doi.org/10.1108/02683940810894747 
Liou, K. T., \& Nyhan, R. C. (1994). Dimensions of organizational commitment in the public sector: An empirical assessment. Public Administration Quarterly, 18(1), 99-118. http://www.jstor.org/stable/40861613

Lo, M. C., Ramayah, T., \& Min, H. W. (2009). Leadership styles and organizational commitment: A test on Malaysia manufacturing industry. African Journal of Marketing Management, 1(6), 133-139.

Lok, P., \& Crawford, J. (2004). The effect of organizational culture and leadership style on job satisfaction and organizational commitment: A cross-national comparison. Journal of Management Development, 23(4), 321-338. http://dx.doi.org/10.1108/02621710410529785

Maccoby, M. (2000). Understanding the difference between management and leadership. Research Technology Management, 43(1), 57-59.

Mandell, B., \& Pherwani, S. (2003). Relationship between emotional intelligence and transformational leadership style: A gender comparison. Journal of Business and Psychology, 17(3), 387-404. http://dx.doi.org/10.1023/A:1022816409059

Mayer, J. D. \& Salovey, P. (1997). What is emotional intelligence? In P. Salovey \& D. Sluyter (Eds.). Emotional development and emotional intelligence: Implications for educators (pp. 3-31). New York: Basic Books.

Meyer, J. P., \& Allen, N. J. (1991). A three-component conceptualization of organizational commitment. Human Resource Management Review, 1(1), 61-89. http://dx.doi.org/10.1016/1053-4822(91)90011-Z

Meyer, J. P., Allen, N. J., \& Smith, C. A. (1993). Commitment to organizations and occupations: Extension and test of a three-component conceptualization. Journal of Applied Psychology, 78(4), 538-551. http://dx.doi.org/10.1037/0021-9010.78.4.538

Meyer, J. P., Paunonen, S. V., Gellatly, I. R., Goffin, R. D., \& Jackson, D. N. (1989). Organizational commitment and job performance: It's the nature of the commitment that counts. Journal of Applied Psychology, 74(1), 152-156. http://dx.doi.org/10.1037/0021-9010.74.1.152

Mohamadkhani, K., \& Nasiri Lalardi, M. (2012). Emotional intelligence and organizational commitment between the hotel staff in Tehran, Iran. American Journal of Business and Management, 1(2), 54-59.

Morris, J. H., \& Steers, R. M. (1993). Structural Influences on Organizational Commitment. Journal of Vocational Behavior, 17(1), 50-57.

Mowday, R. T., Porter, L. W., \& Dubin, R. (1974). Unit performance, situational factors, and employee attitudes in spatially separated work units. Organizational Behavior and Human Performance, 12(2), 231-248. http://dx.doi.org/10.1016/0030-5073(74)90048-8

Mowday, R. T., Porter, L. W., \& Steers, R. M. (1982). Employee-organization linkage. The Psychology of Commitment Absenteism, and Turnover. London: Academic Press Inc.

Mowday, R. T., Steers, R. M., \& Porter, L. W. (1979). The measurement of organizational commitment. Journal of Vocational Behavior, 14(2), 224-247.

Nikolaou, I., \& Tsaousis, I. (2002). Emotional intelligence in the workplace: Exploring its effects on occupational stress and organizational commitment. The International Journal of Organizational Analysis, 10(4), 327-342. http://dx.doi.org/10.1108/eb028956

Northouse, P. G. (2015). Leadership: Theory and practice. Thousand Oaks, CA: Sage publications.

Parasuraman, S., \& Nachman, S. A. (1987). Correlates of Organizational and Professional Commitment The Case of Musicians in Symphony Orchestras. Group \& Organization Management, 12(3), 287-303. http://dx.doi.org/10.1177/105960118701200305

Pearce, C. L., \& Herbik, P. A. (2004). Citizenship behavior at the team level of analysis: The effects of team leadership, team commitment, perceived team support, and team size. The Journal of Social Psychology, 144(3), 293-310. http://dx.doi.org/10.3200/SOCP.144.3.293-310

Peeters, M. C. W., \& Meijer, S. (1995). Commitment in organizations, divisions and the job: A meaningful distinction. Gedrag en Organisatie, 8, 13-164.

Podsakoff, P. M., MacKenzie, S. B., \& Bommer, W. H. (1996). Transformational leader behaviors and substitutes for leadership as determinants of employee satisfaction, commitment, trust, and organizational citizenship behaviors. Journal of Management, 22(2), 259-298. http://dx.doi.org/10.1177/014920639602200204

Popper, M., Mayseless, O., \& Castelnovo, O. (2000). Transformational leadership and attachment. The Leadership Quarterly, 11(2), 267-289. http://dx.doi.org/10.1016/S1048-9843(00)00038-2 
Porter, L. W., Steers, R. M., Mowday, R. T., \& Boulian, P. V. (1974). Organizational commitment, job satisfaction, and turnover among psychiatric technicians. Journal of Applied Psychology, 59(5), 603-609. http://dx.doi.org/10.1037/h0037335

Prati, M. L., Douglas, C., Ferris, G. R., Ammeter, A. P., \& Buckley, M. R. (2003). Emotional intelligence, leadership effectiveness, and team outcomes. The International Journal of Organizational Analysis, 11(1), 21-40. http://dx.doi.org/10.1108/eb028961

Randall, D. M., \& O'driscoll, M. P. (1997). Affective versus calculative commitment: Human resource implications. The Journal of Social Psychology, 137(5), 606-617. http://dx.doi.org/10.1080/00224549709595482

Romzek, B. S. (1990). Employee investment and commitment: The ties that bind. Public Administration Review, 50(3), 374-382.

Salovey, P., \& Mayer, J. D. (1990). Emotional intelligence. Imagination, Cognition and Personality, 9(3), 185-211. http://dx.doi.org/10.2190/DUGG-P24E-52WK-6CDG

Scott-Ladd, B., Travaglione, A., \& Marshall, V. (2006). Causal inferences between participation in decision making, task attributes, work effort, rewards, job satisfaction and commitment. Leadership \& Organization Development Journal, 27(5), 399-414. http://dx.doi.org/10.1108/01437730610677990

Shamir, B., House, R. J., \& Arthur, M. B. (1993). The motivational effects of charismatic leadership: A self-concept based theory. Organization Science, 4(4), 577-594. http://dx.doi.org/10.1287/orsc.4.4.577

Shamir, B., Zakay, E., Breinin, E., \& Popper, M. (1998). Correlates of charismatic leader behavior in military units: Subordinates' attitudes, unit characteristics, and superiors' appraisals of leader performance. Academy of Management Journal, 41(4), 387-409. http://dx.doi.org/10.2307/257080

Stum, D. L. (1999). Workforce commitment: Strategies for the new work order. Strategy \& Leadership, 27(1), 4-7. http://dx.doi.org/10.1108/eb054623

Turner, J. R., \& Lloyd-Walker, B. (2008). Emotional intelligence (EI) capabilities training: Can it develop EI in project teams?. International Journal of Managing Projects in Business, 1(4), 512-534. http://dx.doi.org/10.1108/17538370810906237

Turner, J. R., \& Müller, R. (2005, June). The project manager's leadership style as a success factor on projects: A literature review. Project Management Institute.

Walumbwa, F. O., \& Lawler, J. J. (2003). Building effective organizations: transformational leadership, collectivist orientation, work-related attitudes and withdrawal behaviours in three emerging economies. International Journal of Human Resource Management, 14(7), 1083-1101. http://dx.doi.org/10.1080/0958519032000114219

Ward, E. A., \& Davis, E. (1995). The effect of benefit satisfaction on organizational commitment. Compensation and Benefits Management, 11, 35-35.

Weinberger, L. A. (2003). An examination of the relationship between emotional intelligence, leadership style and perceived leadership effectiveness. Dissertation Abstracts International, 64(11), 5828.

Wong, C. S., \& Law, K. S. (2002). The effects of leader and follower emotional intelligence on performance and attitude: An exploratory study. The Leadership Quarterly, 13(3), 243-274. http://dx.doi.org/10.1016/S1048-9843(02)00099-1

Yammarino, F. J., Spangler, W. D., \& Bass, B. M. (1993). Transformational leadership and performance: A longitudinal investigation. The Leadership Quarterly, 4(1), 81-102. http://dx.doi.org/10.1016/1048-9843(93)90005-E

Yukl, G. A. (1989). Leadership in organizations. India: Pearson Education.

Yukl, G. A. (1999). An evaluation of conceptual weaknesses in transformational and charismatic leadership theories. The Leadership Quarterly, 10(2), 285-305. http://dx.doi.org/10.1016/S1048-9843(99)00013-2

This work is licensed under a Creative Commons Attribution 3.0 License. 